\title{
PENGARUH PEMBERIAN BIOSTIMULAN TERHADAP PERTUMBUHAN DAN HASIL TANAMAN TOMAT (Lycopersicum esculentum Mill.)
}

\section{THE BIOSTIMULANT EFFECT ON TOMATO (Lycopersicum esculentum Mill.) GROWTH AND YIELD}

\author{
Fluenty Dwitama*, Rugayah, Maria Viva Rini, dan Kus Hendarto \\ Jurusan Agroteknologi Fakultas Pertanian Universitas Lampung \\ Jln. Prof Dr. Soemantri Bojonegoro No. 1 Bandar Lampung 35145 \\ *E-mail: fluentydwitama116@gmail.com
}

\begin{abstract}
Tomato (Lycopersicum esculentum Mill.) is one of many widely known vegetables. Based on data from BPS (2018), it shows that tomato production rate is increasing, but tomatoes in Indonesia are still unable to meet the needs of the public. To meet the need for tomatoes, it is necessary to improve cultivation technology, one of which is biostimulant. The research is done to determine how biostimulant affects the growth and yield of tomato plants and determine the best biostimulant to increase the growth and yield of the tomato plant. This research was conducted in the land of Sukabanjar Village, Gedong Tataan Subdistrict, Pesawaran Regency, Lampung Province. The research was conducted in March 2018 to May 2018. This research was arraged in Randomized Block Design (RBD) with a single unstructured factor of 4 treatments, which is No Treatment (0 ml/ha), F \& VBS $184(500 \mathrm{ml} / \mathrm{ha})$, Bio Max Grow $(8000 \mathrm{ml} / \mathrm{ha}), \mathrm{LOB}$ $(6000 \mathrm{ml} / \mathrm{ha})$ with 6 groups and thus gained 24 probationals. Homogeneity of variance was tested using the Bartlet Test and data additivity was tested using the Tukey Test, and continued with the Least Significant Difference Test (LSD) at 5\% for separating the mean values between treatments. The results showed that biostimulants in the form of $L O B$ is significantly affected the growth of the vegetative phase of tomato plants, while biostimulants in the form of $F \& V B S 184$ significantly affected the increase in the generative phase of tomato plants.
\end{abstract}

Keywords: Biostimulant and tomato.

\begin{abstract}
ABSTRAK
Tomat (Lycopersicum esculentum Mill.) merupakan salah satu sayuran yang banyak dikenal masyarakat. Berdasarkan data dari BPS (2018), produksi tomat semakin meningkat, namun produksi tomat di Indonesia belum dapat memenuhi kebutuhan masyarakat. Untuk memenuhi kebutuhan akan tomat, maka perlu dilakukannya peningkatan teknologi budidaya salah satunya biostimulan. Penelitian ini dilakukan untuk mengetahui pengaruh pemberian biostimulan pada pertumbuhan dan hasil tanaman tomat dan menentukan jenis biostimulan terbaik untuk meningkatkan pertumbuhan dan hasil tanaman tomat. Penelitian ini dilaksanakan di lahan Desa Sukabanjar Kecamatan Gedong Tataan Kabupaten Pesawaran Provinsi Lampung pada Maret 2018 hingga Mei 2018. Penelitian ini menggunakan Rancangan Acak Kelompok (RAK) dengan faktor tunggal tidak terstruktur dengan
\end{abstract}


4 perlakuan, yaitu tanpa perlakuan (0 ml/ha), F \& VBS 184 (500 ml/ha), Bio Max Grow (8000 ml/ha), LOB (6000 ml/ha) dengan 6 kelompok yang sekaligus berfungsi sebagai ulangan sehingga diperoleh 24 satuan percobaan. Homogenitas data diuji menggunakan Uji Bartlet dan aditivitas data diuji menggunakan Uji Tukey, dan dilanjutkan dengan Uji Beda Nyata Terkecil (BNT) pada taraf 5\% untuk pemisahan nilai tengah antar perlakuan. Hasil penelitian menunjukkan bahwa pemberian biostimulan LOB berpengaruh dalam meningkatkan pertumbuhan tanaman pada fase vegetatif meliputi tinggi batang dan jumlah cabang, sedangkan biostimulan F \& VBS 184berpengaruh meningkatkan pertumbuhan tanaman pada fase generatif yang meliputi diameter buah, bobot buah per tanaman, dan bobot buah per petak.

Kata kunci: Biostimulan dan Tanaman Tomat.

\section{PENDAHULUAN}

Tomat (Lycopersicum esculentum Mill), merupakan tanaman dari keluarga solanaceae, tumbuhan asli Amerika Tengah dan Selatan, dari Meksiko sampai Peru. Tomat merupakan salah satu jenis sayuran yang sangat dikenal masyarakat Indonesia. Kandungan zat-zat di dalam $100 \mathrm{~g}$ buah tomat berupa 30 kalori, vitamin C $40 \mathrm{mg}$, vitamin A 1.500 S.I, zat besi, dan kalsium (Wiryanta, 2004). Indonesia sebagai negara agraris masih mengandalkan sektor pertanian sebagai sektor yang berperan penting dalam menunjang perekonomian nasional. Badan Pusat Statistik (2017) menyatakan bahwa data produksi tanaman sayuran tomat dalam 3 tahun terakhir terjadi kenaikan yang signifikan. Pada tahun 2015, produksi tomat secara nasional yaitu 877801 ton, tahun 2016 yaitu 883234 ton, dan tahun 2017 yaitu 962849 ton. Namun angka tersebut belum dapat memenuhi permintaan masyarakat akan kebutuhan yang mencapai 1.149.160 ton per tahun, sehingga produksi tomat perlu ditingkatkan. Rendahnya angka produksi tanaman tomat dipengaruhi oleh banyak faktor salah satunya tanah di Provinsi Lampung dominan merupakan tanah ultisol. Ultisol merupakan tanah yang memiliki masalah keasaman tanah, bahan organik rendah dan nutrisi makro rendah dan memiliki ketersediaan P sangat rendah (Fitriatin et.al., 2014). Untuk memenuhi kebutuhan hara tersebut, maka diperlukan teknologi baru yang dapat memaksimalkan kerja tanah yang dapat dilakukan dengan pengaplikasian biostimulan yang merupakan upaya untuk meningkatkan produktivitas tanaman pada kondisi cekaman abiotik (Calvo et al., 2014). Teknologi biostimulan tanaman telah banyak diaplikasikan untuk meningkatkan produktivitas tanaman semusim(Rouphael et al., 2017). Penelitian ini bertujuan untuk mengetahui pengaruh pemberian biostimulan pada pertumbuhan dan hasil tanaman tomat dan menentukan jenis biostimulan terbaik untuk meningkatkan pertumbuhan dan hasil tanaman tomat.

\section{BAHAN DAN METODE}

Penelitian ini dilaksanakan di lahan Desa Sukabanjar Kecamatan Gedong Tataan Kabupaten Pesawaran Provinsi Lampung. Penelitian dilaksanakan pada Maret 2018 hingga Mei 2018. Alat yang 
digunakan pada penelitia ini antara lain:cangkul, bambu, gunting, ember, timbagan, gelas ukur, ph meter, thermometer, tali rapia, meteran, dan alat tulis. Bahan yang digunakan antara lain:benih tomat varietas Betavila F1 dengan merek dagang Cap Panah Merah, F \& VBS 184, Bio Max Grow, LOB. Penelitian ini menggunakan rancangan percobaan Rancangan Acak Kelompok dengan rancangan perlakuan tunggal tidak terstruktur yang terdiri dari 4 perlakuan yaitu Tanpa perlakuan, $\mathrm{F}$ \& VBS 184, Bio Max Grow, dan LOB dengan 6 ulangan. Setiap perlakuan terdiri dari 16 tanaman tomat yang ditanam pada 1 guludan dengan ukuran $5 \times 1 \mathrm{~m}$ per guludan dan jarak tanam $60 \mathrm{~cm} \times 40 \mathrm{~cm}$. Sehingga total tanaman seluruhnya adalah 384 tanaman tomat. Tiap perlakuan diambil masing-masing 2 tanaman sampel, sehingga total sampel yang diamati berjumlah 48 tanaman. Pengaplikasian biostimulan dibagi menjadi 2 tahap, pemberian dilakukan pada saat tanaman masih dalam fase vegetatif, pengaplikasian pada tahap ke 1 dilakukan saat tanaman berumur 10 HST dan pengaplikasian pada tahap ke 2 dilakukan 14 hari setelah pengaplikasian pertama. Pengaplikasian pupuk biostimulan dan PPC sesuai dosis yang di anjurkan yaitu: pupuk F \& VBS 184 (500 ml/ha), pupuk Bio
Max Grow (8000 ml/ha), dan pupuk LOB (6000 ml/ ha). Pengaplikasian pupuk biostimulan dilakukan dengan cara pengenceran menggunakan air $(\mathrm{ml} /$ perlakuan) yang kemudian disiram pada lubang tanam sebanyak $15 \mathrm{ml} /$ tanaman. Pengamatan yang dilakukan yaitu menghitung tinggi batang, jumlah cabang, diameter buah, volume buah, jumlah buah per tanaman, bobot buah per tanaman, bobot buah per petak. Data yang diperoleh pada setiap percobaan dilakukan uji homogenitas ragam dengan menggunakan uji Barlet dan aditifitas data diuji dengan menggunakan uji Tukey. Apabila uji Tukey terpenuhi, selanjutnya data dianalisis dengan analisis ragam, jika uji F signifikan maka dilanjutkan dengan Uji Beda Nyata Terkecil (BNT) pada taraf $5 \%$.

\section{HASIL DAN PEMBAHASAN}

\section{Tinggi batang}

Pengamatan terhadap tinggi batang tomat yang telah dilakukan, diperoleh hasil bahwa perlakuan pemberian biostimulan berpengaruh nyata terhadap variabel tinggi tanaman umur 6 mst. Perlakuan biostimulan LOB menunjukan hasil tertinggi dan berbeda nyata dengan semua perlakuan (Tabel 1).

Tabel 1. Pengaruh pemberian biostimulan terhadap variabel tinggi batang $6 \mathrm{MST}$

\begin{tabular}{|c|c|}
\hline Perlakuan & Rerata Tinggi Batang \\
\hline Tanpa Perlakuan & $81,74 \mathrm{~b}$ \\
\hline F\&VBS $184(500 \mathrm{ml} / \mathrm{ha})$ & $78,36 \mathrm{~b}$ \\
\hline Bio Max Grow (8000 ml/ha) & $84,96 \mathrm{~b}$ \\
\hline LOB (6000 ml/ha) & $96,16 \mathrm{a}$ \\
\hline BNT 5\% & 10,19 \\
\hline
\end{tabular}

Keterangan: Nilai tengah pada kolom yang diikuti huruf yang sama tidak berbeda nyata menurut uji BNT pada taraf 5\%. 
Tabel 2. Pengaruh pemberian biostimulan terhadap variabel jumlah cabang 6 MST

\begin{tabular}{|c|c|}
\hline Perlakuan & Rerata Jumlah Cabang \\
\hline Tanpa Perlakuan & $17,50 \mathrm{~b}$ \\
\hline F\&VBS 184 (500 ml/ha) & $17,17 \quad b$ \\
\hline Bio Max Grow (8000 ml/ha) & $20,00 \mathrm{ab}$ \\
\hline LOB $(6000 \mathrm{ml} / \mathrm{ha})$ & $22,50 \quad \mathrm{a}$ \\
\hline BNT 5\% & 3,21 \\
\hline
\end{tabular}

Keterangan: Nilai tengah pada kolom yang diikuti huruf yang sama tidak berbeda nyata menurut uji BNT pada taraf 5\%.

Tabel 3. Pengaruh pemberian biostimulan terhadap variabel diameter buah

\begin{tabular}{lc}
\hline \multicolumn{1}{c}{ Perlakuan } & Rerata Diameter Buah \\
\hline Tanpa Perlakuan & $3,81 \mathrm{~b}$ \\
F\&VBS $184(500 \mathrm{ml} / \mathrm{ha})$ & $4,22 \mathrm{a}$ \\
Bio Max Grow $(8000 \mathrm{ml} / \mathrm{ha})$ & $4,15 \mathrm{a}$ \\
LOB $(6000 \mathrm{ml} / \mathrm{ha})$ & $3,77 \mathrm{~b}$ \\
\hline BNT $5 \%$ & 0,21 \\
\hline
\end{tabular}

Keterangan: Nilai tengah pada kolom yang diikuti huruf yang sama tidak berbeda nyata menurut uji BNT pada taraf 5\%.

\section{Jumlah cabang}

Berdasarkan hasil penelitian yang telah dilakukan, diperoleh bahwa perlakuan pemberian biostimulan nyata meningkatkan jumlah cabang 6 mst. Perlakuan pemberian biostimulan berupa LOB menunjukkan hasil yang berbeda nyata dengan tanpa perlakuan dan F \& VBS184, namun relatif sama dengan perlakuan Bio Max Grow (Tabel 2).

\section{Diameter buah}

Hasil penelitian menunjukkan bahwa pemberian biostimulan nyata meningkatkan variabel diameter buah. Perlakuan pemberian biostimulan F\&VBS 184 menunjukkan hasil tertinggi dan berbeda nyata dengan tanpa perlakuan dan LOB namun tidak berbeda nyata dengan perlakuan Bio Max Grow (Tabel 3).

\section{Volume Buah}

Hasil penelitianmenunjukkan bahwa perlakuan pemberian biostimulan tidak berpengaruh nyata terhadap variabel volume buah. Uji lanjut terhadap variabel volume buah tidak dilakukan karena tidak terdapat pengaruh dari perlakuan yang diberikan.

\section{Jumlah buah}

Berdasarkan pengamatan pada variabel jumlah buah per tanaman, diperoleh hasil bahwa perlakuan pemberian biostimulan berpengaruh nyata. Perlakuan pemberian biostimulan berupa LOB menunjukkan hasil tertinggi berbeda nyata dengan semua perlakuan(Tabel4).

\section{Bobot buah per tanaman}

Pengamatan pada variabel bobot buah per tanaman menunjukkan bahwa perlakuan pemberian biostimulan berpengaruh nyata. Perlakuan biostimulan berupa F\&VBS 184 menunjukan hasil tertinggi berbeda nyata dengan semua perlakuan (Tabel 5).

\section{Bobot buah per petak}

Hasil penelitian menunjukkan bahwa perlakuan pemberian biostimulan berpengaruh nyata terhadap 
Tabel 4. Pengaruh pemberian biostimulan terhadap variabel jumlah buah per tanaman

\begin{tabular}{lc}
\hline \multicolumn{1}{c}{ Perlakuan } & Rerata Jumlah Buah \\
\hline Tanpa Perlakuan & $23,67 \quad \mathrm{~b}$ \\
F\&VBS $184(500 \mathrm{ml} / \mathrm{ha})$ & $22,33 \quad \mathrm{~b}$ \\
Bio Max Grow $(8000 \mathrm{ml} / \mathrm{ha})$ & $21,17 \mathrm{~b}$ \\
LOB $(6000 \mathrm{ml} / \mathrm{ha})$ & $29,83 \quad$ a \\
\hline BNT 5\% & 3,93 \\
\hline
\end{tabular}

Keterangan: Nilai tengah pada kolom yang diikuti huruf yang sama tidak berbeda nyata menurut uji BNT pada taraf 5\%.

Tabel 5. Pengaruh pemberian biostimulan terhadap variabel bobot buah per tanaman

\begin{tabular}{lc}
\hline \multicolumn{1}{c}{ Perlakuan } & Rerata Bobot Buah Per Tanaman $(\mathrm{g})$ \\
\hline Tanpa Perlakuan & $919,07 \mathrm{~b}$ \\
F\&VBS $184(500 \mathrm{ml} / \mathrm{ha})$ & $1061,90 \mathrm{a}$ \\
Bio Max Grow $(8000 \mathrm{ml} / \mathrm{ha})$ & $957,41 \mathrm{~b}$ \\
LOB $(6000 \mathrm{ml} / \mathrm{ha})$ & $961,09 \mathrm{~b}$ \\
\hline \multicolumn{1}{c}{ BNT 5\% } & 87,80 \\
\hline
\end{tabular}

Keterangan: Nilai tengah pada kolom yang diikuti huruf yang sama tidak berbeda nyata menurut uji BNT pada taraf $5 \%$.

Tabel 6. Pengaruh pemberian biostimulan terhadap variabel bobot buah per petak

\begin{tabular}{lc}
\hline \multicolumn{1}{c}{ Perlakuan } & Rerata bobot buah per petak $(\mathrm{g})$ \\
\hline Tanpa Perlakuan & $8.637,91 \mathrm{~b}$ \\
F\&VBS $184(500 \mathrm{ml} / \mathrm{ha})$ & $11.315,75 \mathrm{a}$ \\
Bio Max Grow $(8000 \mathrm{ml} / \mathrm{ha})$ & $9.622,69 \mathrm{~b}$ \\
LOB $(6000 \mathrm{ml} / \mathrm{ha})$ & $9.352,20 \mathrm{~b}$ \\
\hline \multicolumn{2}{c}{ BNT 5\% } \\
\hline
\end{tabular}

Keterangan: Nilai tengah pada kolom yang diikuti huruf yang sama tidak berbeda nyata menurut uji BNT pada taraf 5\%.

variabel bobot buah per petak. Perlakuan pemberian biostimulan berupa F \& VBS184 menunjukan hasil tertinggiberbedanyata dengan semua perlakuan(Tabel6).

\section{Pengaruh pemberian biostimulan pada pertumbuhan vegetatif tanaman tomat}

Hasil penelitian menunjukkan bahwa pemberian biostimulan mampu meningkatkan pertumbuhan tanaman tomat. Pemberian biostimulan berpengaruh nyata dalam meningkatkan variabel tinggi batang dan jumlah cabang. Hasil analisis data menunjukkan bahwa perlakuan LOB(Liquid Organic Biofertilizer) lebih meningkatkan pertumbuhan tinggi tanaman dan jumlah cabang namun tidak berbeda nyata dengan perlakuan Bio Max Grow. Hal ini karena kandungan mikroorganisme padaLOB(Liquid Organic Biofertilizer) seperti yang tertera pada label kemasan bahwa dalam LOB (Liquid Organic Biofertilizer) terdapatAzotobacter sp. dan Azospirillum sp. yang lebih tinggi kepadatannya dibandingkan dengan yang terkandung dalam Bio Max Grow. Berdasarkan keterangan pada brosur bahwa Bio Max Grow 
mengandung Azotobacter sp. 2,0 x 10 $10^{7} \mathrm{cfu} / \mathrm{ml}$ dan Azospirillum sp. $7,1 \times 10^{7} \mathrm{cfu} / \mathrm{ml}$, sedangkan LOB mengandung Azotobacter sp. $1,02 \times 10^{8} \mathrm{cfu} / \mathrm{ml}$ dan Azospirillum sp3,12 x $10^{8} \mathrm{cfu} / \mathrm{ml}$.

\section{LOB (Liquid Organic Biofertilizer)} mengandung mikroorganisme salah satunya Azotobacter sp.,Azospirillum sp., dan Pseudomonas sp. yang baik bagi pertumbuhan tanaman. Mikroorganisme Azotobacter sp. dan Azospirillum sp. merupakan mikroorganisme yang dapat meningkatkan pertumbuhan tanaman melalui fiksasi $\mathrm{N}_{2}$ menjadi $\mathrm{NO}_{3}$ yang mampu diserap oleh tanaman. Menurut Marsono (2001) unsur $\mathrm{N}$ berfungsi untuk memacu pertumbuhan tanaman dan berperan dalam pembentukan klorofil, lemak, protein, dan senyawa lainnya, yang mana kandungan tersebut sangat dibutuhkan dalam proses pertumbuhan tanaman. Kandungan mikroorganisme Pseudomonas sp. yang berfungsi sebagai bakteri pelarut $\mathrm{P}$ mampu membantu pertumbuhan tanaman dengan cara melarutkan $P$ tidak terlarut. Sesuai yang dikatakan Roesmarkam (2002) menyatakan untuk pertumbuhan yang optimal selama fase vegetatif, unsur $\mathrm{N}$ harus diimbangi dengan unsur yang lain seperti unsur P. Sehingga pada perlakuan LOB pertumbuhan tanaman tomat selama fase vegetatif sangat tertunjang dengan baik. Sesuai dengan penelitian lain yang telah dilakukan, membuktikan bahwa pemberian Azotobacter sp. berpengaruh nyata dalam meningkatkan tinggi tanaman cabai (Saddam et al., 2017). Beberapa penelitian lain yang telah dilakukan, juga membuktikan bahwa pemberian Pseudomonas sp. yang diberi pupuk dasar N, P, K mampu meningkatkan tinggi tanaman tomat hingga $25,44 \mathrm{~cm}$, dan berbeda nyata dengan tanaman yang tanpa pemberian Pseudomonas sp. (Sumarni et al., 2015).

\section{Pengaruh pemberian biostimulan pada pertumbuhan generatif tanaman tomat}

Hasil penelitian menunjukkan bahwa pemberian biostimulan berpengaruh nyata dalam meningkatkan variabel diameter buah, jumlah buah per tanaman, bobot buah per tanaman dan bobot buah per petak, namun tidak berpengaruh nyata pada variabel volume buah. Berdasarkan analisis data menunjukkan bahwa pemberian biostimulan berpengaruh nyata pada variabel diameter buah. Perlakuan Bio Max Grow dan F\&VBS 184 dapat memberikan hasil terbaik pada diameter buah. Hal ini dikarnakan kandungan mikroorganisme dalam Bio Max Grow yang mampu menambat unsur nitrogen dari udara dan mikroba yang dapat melarutkan unsur fosfor dan kalium dalam keadaan yang tidak dapat diserap oleh tanaman menjadi dapat diserap oleh tanaman (Hanafiah et al., 2007). Kandungan yang terdapat pada F\&VBS 184 yaitu mikroorganisme pelarut $\mathrm{P}$ yang mampu mengubah fosfat tidak terlarut menjadi terlarut. Mikroorganisme pelarut P mengubah $\mathrm{P}$ tidak terlarut dengan cara mensekresikan asam organik seperti asam format, asetat, propionate, laktat, glikolat, fumarat, dan suksinat (Suliasih et al., 2010). Berdasarkan analisis data pada variabel jumlah buah menunjukkan bahwa perlakuan LOB (Liquid Organic Biofertilizer) mampu memberikan hasil terbaik namun buah yang dihasilkan relatif kecil. 
Hasil analisis data menunjukkan bahwa pemberian F\&VBS 184 berpengaruh nyata terhadap variabel bobot buah per tanaman maupun bobot buah per petak.. Hal ini didukung dengan diameter dan volume buah yang menunjukkan hasil tertinggi, dan didukung dengan bobot buah per tanaman sehingga bobot total menunjukan bahwa pemberian F\&VBS 184 mampu meningkatkan hasil tanaman tomat. F\&VBS 184 merupakan mikroorganisme yang mampu melarutkan P agar dapat diserap oleh tanaman. Mikroorganisme pelarut P antara lain: Aspergillus sp., Penicillium sp., Pseudomonas sp., dan Bacillus sp. Mikroba yang berkemampuan tinggi melarutkan $\mathrm{P}$ umumnya juga mampu mempengaruhi kelarutan $\mathrm{K}$ (Sumarni et al., 2015). Unsur P dan unsur K secara bersamaan sangat dibutuhkan dalam pembentukan bunga dan buah. Pseudomonas sp berfungsi untuk memproduksi antibiotic pelindung penyakit, menjadi pesaing pathogen penyebab penyakit disekitar perakaran, merangsang pembentukan hormon atau ZPT auksin, sitokinin, dan giberelin, meningkatkan ketersediaan unsur Mn, P, dan K (Dermiyati, 2015). Bacillus sp. bermanfaat bagi tanaman sebagai pelarut fosfat $(\mathrm{P})$ dan kalium $(\mathrm{K})$, mereduksi ?Fe?^$^{\wedge}\left(3^{+}\right)$ menjadi ?Fe?^(2+), medegredasikan residu kimia dalam tanah, dan memproduksi enzim (Dermiyati, 2015). Berdasarkan analisis data di atas menunjukkan bahwa Bio Max Grow berpotensi memberikan hasil yang lebih baik namun banyak buah yang rusak disebabkan oleh Blossom end rot dan terserang ulat buah. Potensi terjadinya kerusakan buah disebabkan penelitian ini tidak menggunakan pestisida maupun fungisida dan cuaca penghujan. Kemampuan tanaman tomat untuk dapat menghasilkan buah sangat tergantung pada interaksi antara pertumbuhan tanaman dan kondisi lingkungannya (Wijayani dan Widodo, 2005). Berdasarkan hasil penelitian bahwa pada perlakuan LOB (Liquid Organic Biofertilizer) menunjukkan pertumbuhan vegetatif yang lebih dominan dibandingkan pertumbuhan generatif, sedangkan pada perlakuan F\&VBS 184 menunjukkan adanya keseimbangan pertumbuhan antara vagetatif dan generatif. Pada tanaman yang memiliki panen utamanya merupakan buah, maka sangatlah penting untuk memiliki keseimbangan pertumbuhan antara vegetatif dan generatif. Diduga terjadinya persaingan bahan organik yang berfungsi sebagai sumber nutrisi atau sumber makanan bagi mikroorganisme, karena pada biostimulan LOB mengandung banyak jenis mikroorganisme sehingga semakin besar kemungkinan terjadinya persaingan nutrisi antar mikroorganisme tersebut, dibandingkan dengan biostimulan F\&VBS 184 yang hanya mengandung satu jenis mikroorganisme saja. Sehingga persaingan perebutan nutrisi tersebut dapat mengganggu kinerja dari mikroorganisme itu sendiri.

Keseimbangan pertumbuhan antara vegetatif dan generatif sendiri sangat dipengaruhi dengan ketersediaannya unsur hara makro yaitu nitrogen, fosfor, dan kalium. Tanaman tomat membutuhkan ketiga unsur hara tersebut dalam jumlah yang relatif banyak, bila ketiga unsur hara ini tidak tersedia atau tersedia terlalu lambat, atau berada tidak dalam keseimbangan, maka perkembangan tanaman akan 
terhambat (Sarwono 1995). Apabila kekurangan N,P,K maka akan menghambat pertumbuhan vegetatif tanaman dan sebaliknya akan memperpanjang fase pemasakan buah (Firmansyah et al., 2017). Hasil penelitian pada perlakuan F\&VBS 184 bila dibandingkan dengan produksi tomat nasional menunjukkan tidak meningkatkan produksi tomat. Menurut BPS (2017) produksi tomat nasional menghasilkan 17,31 ton/ha, sedangkan pada perlakuan F\&VBS 184 hanya mampu menghasilkan 22,64 ton/ha.

\section{KESIMPULAN}

Pemberian biostimulan nyata meningkatkan pada variabel tinggi batang, jumlah cabang, diameter buah, bobot buah per tanaman, dan bobot buah per petak. Perlakuan LOB (Liquid Organic Biofertilizer) lebih meningkatkan pertumbuhan pada fase vegetatif, terutama pada tinggi batang dan jumlah cabang dibandingkan dengan F\&VBS 184, sedangkan perlakuan F\&VBS 184 dan lebih meningkatkan pertumbuhan pada fase generatif, terutama pada diameter buah, bobot buah per tanaman, dan bobot buah per petak dibandingkan dengan LOB.

\section{UCAPAN TERIMAKASIH}

Ucapan terimakasih kepada Ibu Ir. Rugayah, M.P., Ibu Dr. Ir. Maria Viva Rini, M.Sc., Bapak Ir. Kus Hendarto, M.S yang telah membimbing dan membantu saya dalam penelitian ini dan kepada PT. Bina Guna Kimia (An FMC Joint Venture Company) yang telah memberikan pendanaan pada penelitian ini.

\section{DAFTAR PUSTAKA}

Badan Pusat Statistik. 2017. Statistik Tanaman Sayuran dan Buah-buahan Semusim. Badan Pusat Statistik. Jakarta. 12 p. ISSN : 2088-8392

Calvo, P. L., Nelson, L., dan Kloepper, J. 2014. Agricultural uses of plant biostimulants. J. Plant Soil 383: 3-41.

Dermiyati. 2015. Sistem pertanian organik. Plantaxia. Lampung. 48 p. ISBN : 978-602-6912-01-5

Firmansyah, I., Muhammad, S., dan Liferdi, L. 2017. Pengaruh kombinasi dosis pupuk n, p, dan k terhadap pertumbuhan danhasil tanaman terung (Solanum melongena L.). J. Hort 27 (1) : 69-78.

Fitriatin, B. N., Yuniarti, A., Turmuktini, T., dan Ruswandi, F. K. 2014. The Effect of Phosphate Solubilizing Microbe Producing Growth Regulators on Soil Phosphate, Growth and Yield of Maize and Fertilizer Efficiency on Ultisol. Eurasian J. of Soil Sci. Indonesia. 3 (1) : 101-107. ISSN: 2147-4249

Hanafiah, K. A. N., Napoleon, dan Ghofar. 2007. Biologi tanah : ekologi dan makrobiologi tanah 1-2. PT. Rajawali Grafindo Persada. Jakarta

Oosten, M. J. V., Pepe, O., Pascale, S. D., Silletti, S., \& AMaggio (2017). The role of biostimulants and bioeffectors as alleviators of abiotic stress in crop plants. J. Chem. Biol. Technol. Agric 4 (5) : 1-12. DOI : 10.1186/s40538-017-0089-5

Rouphael, Y., Cardarelli, M., Bonini, P., and Colla, G. 2017. Synergistic action of a microbial-based biostimulant and a plant derived-protein hydrolysate enhances lettuce tolerance to alkalinity and salinity. J. Frontiers in Plant Science 8 (131): 1-12. DOI : 10.3389/ $\underline{\text { FPLS.2017.00131 }}$ 
Saddam, P. T., Iskandar, M. L., dan Henry, N. B. 2017. Aplikasi kompos dan azotobacter sp. terhadap pertumbuhan dan produksi tanaman cabai merah (Capsicum annuum L.). J. Agrotekbis 5 (3) : $291-299$

Sarwono, H. 1995. Ilmu Tanah. Akademik Pressindo. Jakarta. 87 p. ISBN : 9789798035562

Suliasih, S.,Widawati, dan Muharam,A. 2010.Aplikasi pupuk organik dan bakteri pelarut fosfat untuk meningkatkan pertumbuhan tanaman tomat dan aktivitas mikroba tanah. J. Hort 20(3): 241-246.

Sumarni, A., Aiyen dan Panggeso, J. 2015. Pseudomonas sp. strain dsmz 13134 dan efektivitasnya pada pertumbuhan tanaman tomat (Lycopersicum esculentum Mill.) serta serapan p pada tanah masam. e-J. Agrotekbis 3 (3) : 338 - 344. ISSN : 2338-3011

Wijanarko, A. Sudaryono dan Sutarno. 2007. Karakteristik Sifat Kimia dan Fisika Tanah Alfisol di Jawa Timur dan Jawa Tengah. Iptek TanamanPangan. Malang

Wijayani, A. dan Widodo, W. 2005. Usaha meningkatkan kualitas beberapa varietas tomat dengan system budi daya hidroponik. J Ilmu Pertanian 12 (1): 77-83.

Wiryanta,W. T. B. 2004. Bertanam Tomat.Agromedia Pustaka. Jakarta. 102 p. ISBN: 979-3084-28-6 